\title{
ANALISIS PENERAPAN BRILINK DI BANK BRI KOTA MADIUN SEBAGAI UPAYA MENDORONG FINANCIAL INCLUSION
}

\author{
Herman Ahmadi ${ }^{1}$ \\ Universitas PGRI Madiun \\ herogasjaya@gmail.com
}

\begin{abstract}
The role of the financial system becomes relatively important in a country's economy in today's globalization era. The financial sector as part of the economic backer of the state has an important task in supporting the economic activities of the poor so that they can still do its activities. According to Bank Indonesia the form of an inclusive financial national strategy is the right of everyone to have access and full service from financial institutions in a timely, , informative, and affordable costs, with full respect for the dignity and prestige of PT. BRI (Persero), Tbk. Madiun Branch Office is one of the branch offices of PT. Bank Rakyat Indonesia (Persero), Tbk. His job is to carry out all orders that have been established by the head office and provide banking products services, including being a manager of BRILink for Madiun and surrounding areas.

Research Objectives Describe the sustainability of BRILink services, as well as describe the barriers that exist in the implementation of BRILink PT. BRI (Persero), and the successful implementation of BRILink PT. BRI (Persero), Tbk. Branch Office Madiun can encourage financial inclusion in Madiun and surrounding areas.

$A$ well-developed financial sector will encourage economic activity, PT. BRI (Persero), Tbk. Branch Office Madiun can only be enjoyed by the city community freely. The low level of public financial literacy and the geographic condition of the Madiun region that is not accessible by access to banking services are the factors that hinder financial inclusion. and must fix itself from the many obstacles in the implementation of BRIlink so that more users and agents can improve the quality of life due to the ease of service BRIlink, PT. BRI (Persero), Tbk. Madiun Branch Offices often evaluate the implementation of BRIlink, as well as minimize constraints, and increase training in the use of EDC machines
\end{abstract}

Keyword : Brillink

Peranan sistem keuangan menjadi relatif penting dalam suatu perekonomian negara di era globalisasi dewasa ini. Sektor keuangan sebagai bagian dari penyokong perekonomian negara mempunyai tugas penting dalam mendukung kegiatan ekonomi masyarakat miskin agar mereka tetap dapat melakukan kegiatannya, Menurut Bank Indonesia bentuk strategi nasional keuangan inklusif yaitu hak setiap orang untuk memiliki akses dan layanan penuh dari lembaga keuangan secara tepat waktu, nyaman, informatif, dan terjangkau biayanya, dengan penghormatan penuh kepada harkat dan martabatnya, PT. BRI (Persero), Tbk. Kantor Cabang Madiun merupakan salah satu kantor cabang dari PT. Bank Rakyat Indonesia (Persero), Tbk. Tugasnya adalah menjalankan segala perintah yang telah ditetapkan oleh kantor pusat dan memberikan layanan produk perbankan, termasuk menjadi pengelola BRILink untuk wilayah Madiun dan sekitarnya.

Tujuan Penelitian Mendeskripsikan keberlangsungan layanan BRILink,serta mendiskripsikan hambatan-hambatan yang ada pada penerapan BRILinkPT. BRI (Persero), serta keberhasilan penerapan BRILinkPT. BRI (Persero), Tbk. Kantor Cabang Madiun dapat mendorong financial inclusion di wilayah Madiun dan sekitarnya.

Sektor keuangan yang berkembang dengan baik akan mendorong kegiatan perekonomian ,PT. BRI (Persero), Tbk. Kantor Cabang Madiun hanya bisa dinikmati oleh masyarakat kota dengan leluasa. Tingkat literasi keuangan masyarakat yang rendah serta kondisi geografis wilayah Madiun yang tidak terjangkau oleh akses layanan perbankan merupakan faktor-faktor yang menghambat financial inclusion.serta harus membenahi diri dari banyaknya hambatan-hambatan dalam penerapan BRIlink sehingga pengguna dan agen lebih dapat meningkatkan kualitas hidup karena kemudahan layanan BRIlink,PT. BRI (Persero), Tbk. Kantor Cabang Madiun sering 
INVENTORY

Jurnal Akuntansi, Prodi. Akuntansi - FEB, UNIPMA, Vol. 1, No.2, April 2018

melakukan evaluasi pada penerapan BRIlink ,serta meminimalkan kendala,serta memperbanyak pelatihan dalam penggunaan mesin EDC

Kata Kunci : Brillink

PENDAHULUAN

Peranan sistem keuangan menjadi relatif penting dalam suatu perekonomian negara di era globalisasi dewasa ini. Sektor keuangan sebagai bagian dari penyokong perekonomian negara mempunyai tugas penting dalam mendukung kegiatan ekonomi masyarakat miskin agar mereka tetap dapat melakukan kegiatannya. Pembangunan sektor keuangan, terutama sektor perbankan, dapat meningkatkan akses dan penggunaan jasa perbankan oleh masyarakat. Semakin terbukanya akses terhadap jasa keuangan, masyarakat diharapkan dapat memanfaatkan akses tersebut serta meningkatkan pendapatannya melalui penyaluran kredit oleh lembaga keuangan terutama apabila digunakan untuk kegiatan produktif. Sulitnya akses terhadap jasa keuangan menyebabkan masyarakat miskin harus mengandalkan tabungan yang terbatas untuk investasi dan pengusaha kecil harus mengandalkan laba untuk meneruskan usaha.

Masih banyaknya anggota masyarakat yang belum mengenal, menggunakan atau mendapatkan layanan perbankan dan layanan keuangan lainnya, antara lain karena bertempat tinggal di lokasi yang jauh dari kantor bank atau adanya biaya atau persyaratan yang memberatkan membuat pemerintah saat ini gencar dalam hal perencanaan dan pelaksanaan strategi nasional untuk mencapai keuangan inklusif. Strategi nasional untuk mencapai keuangan inklusif dilaksanakan oleh Otoritas Jasa Keuangan selanjutnya disebut dengan OJK, Industri Perbankan, dan industri jasa keuangan lainnya. Menurut Peraturan Otoritas Jasa Keuangan Nomor 19/POJK/.03/2014 tentang Layanan Keuangan Tanpa Kantor dan Rangka Keuangan Inklusif, yang dimaksud dengan keuangan inklusif adalah keadaan dimana seluruh masyarakat dapat menjangkau akses layanan keuangan secara 
INVENTORY

Jurnal Akuntansi, Prodi. Akuntansi - FEB, UNIPMA, Vol. 1, No.2, April 2018

mudah dan memiliki budaya

mengoptimalkan penggunaan jasa

keuangan. Financial inclusion

berkaitan dengan kemudahan dalam

mengakses dan menggunakan jasa

keuangan (Sarma, 2012). Menurut

Bank Indonesia (2014), financial

inclusion (keuangan inklusif)

didefinisikan sebagai "bentuk

strategi nasional keuangan inklusif

yaitu hak setiap orang untuk

memiliki akses dan layanan penuh

dari lembaga keuangan secara tepat

waktu, nyaman, informatif, dan

terjangkau biayanya, dengan

penghormatan penuh kepada harkat

dan martabatnya." Dari sisi makro,

program ini diharapkan dapat

memberikan manfaat kesejahteraan

bagi rakyat banyak karena

masyarakat Indonesia masih

banyak yang belum bisa mengakses

pelayanan jasa lembaga keuangan

perbankan. Hal ini menjadi

perhatian Bank Indonesia untuk

mendorong sistem lembaga

keuangan perbankan agar dapat

diakses di seluruh lapisan

masyarakat. Sistem keuangan yang

inklusif akan mampu

memberdayakan individu untuk mampu mengakses layanan keuangan seperti tabungan, kredit, asuransi, dana pensiun, dan fasilitas pembayaran, sehingga sangat membantu masyarakat khususnya kelompok berpendapatan rendah untuk meningkatkan pendapatannya, mengakumulasikan kekayaannya, dan mengelola risiko, serta upaya untuk keluar dari kemiskinan.

Hasil Survey Neraca Rumah Tangga yang dilakukan oleh Bank Indonesia pada tahun 2011, yang menyebutkan bahwa $62 \%$ rumah tangga tidak memiliki tabungan sama sekali (Sarah, 2015). Fakta tersebut sejalan dengan hasil studi World Bank tahun 2011 yang menyatakan bahwa hanya separuh dari penduduk Indonesia yang memiliki akses ke sistem keuangan formal. Data dari Bank Indonesia tahun 2013, diketahui bahwa Indonesia memiliki persentase terendah sebesar $\quad 19,6 \%$ dibandingkan negara-negara lain. Pada tahun 2016, terjadi peningkatan indeks literasi dan inklusi keuangan di Indonesia. Hasil Survei Nasional Literasi dan 
INNENTORY

Jurnal Akuntansi, Prodi. Akuntansi - FEB, UNIPMA, Vol. 1, No.2, April 2018

Inklusi Keuangan (SNLIK) kedua yang dilakukan Otoritas Jasa Keuangan (OJK) pada tahun 2016 menunjukkan indeks literasi keuangan sebesar $29,66 \%$ dan indeks inklusi keuangan sebesar 67,82\% (OJK, 2017). Angka tersebut meningkat dibandingkanhasil SNLIK pada tahun 2013, yaitu indeks literasi keuangan $21,84 \%$ dan indeks inklusi keuangan 59,74\%.

Keberhasilan pemerintah Indonesia melalui Otoritas Jasa Keuangan (OJK) dalam meningkatkan indeks inklusi keuangan Indonesia tidak terlepas dari berbagai usaha yang dilakukan, salah satunya adalah melalui produk perbankan berupa program layanan branchless banking atau yang selanjutnya disebut dengan Laku Pandai (Layanan Keuangan Tanpa Kantor dalam Rangka Keuangan Inklusif). Hal ini sejalan dengan hasil penelitian yang dilakukan Hedge dan Kotian (2016) bahwa branchless banking memiliki dampak positif terhadap financial inclusion. Sebagai bagian dari financial inclusion, branchless banking telah menjadi alat yang efektif untuk menyediakan layanan perbankan dasar bagi masyarakat dengan tingkat perekonomian rendah dan dapat disebut sebagai sarana yang efektif dalam penghematan biaya dan waktu pengaksesan layanan perbankan bagi masyarakat.

Berkaitan dengan kegiatan branchless banking, maka mendorong lembaga perbankan di Indonesia untuk mengembangkan berbagai layanan perbankan yang mendukung program financial inclusion di Indonesia. Salah satunya adalah PT. Bank Rakyat Indonesia (Persero), Tbk. atau Bank BRI, yang telah mengembangkan inovasi layanan produk yang mampu memahami kemudahan dan keamanan bertransaksi secara online, yaitu dengan meluncurkan BRILink. Layanan produk BRILink ini merupakan bagian dari dukungan BRI pada program Pemerintah yakni financial inclusion. Program ini adalah salah satu terobosan BRI untuk mengedukasi masyarakat Indonesia, dalam mengenal 
INNENTORY

Jurnal Akuntansi, Prodi. Akuntansi - FEB, UNIPMA, Vol. 1, No.2, April 2018

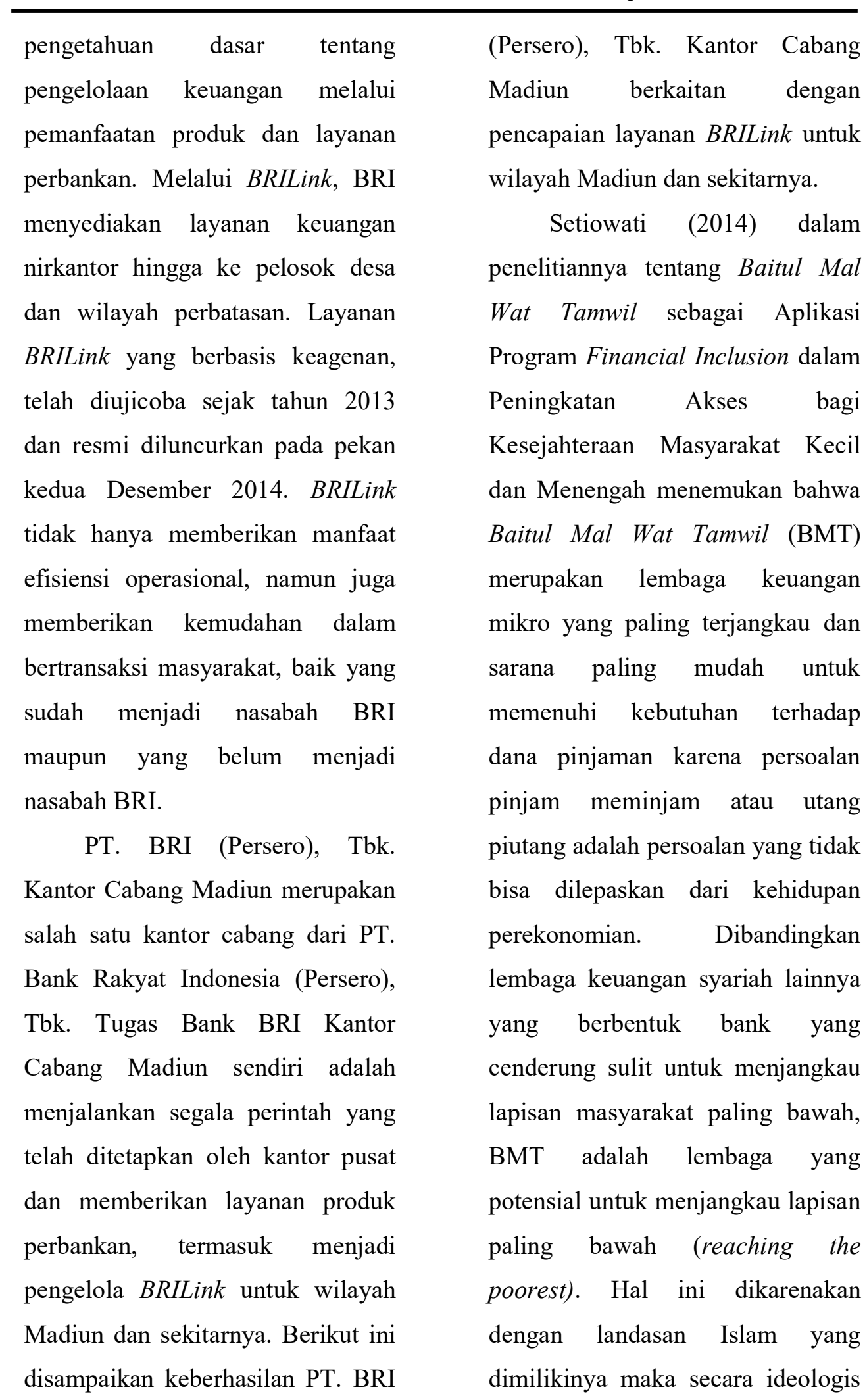


INVENTORY

Jurnal Akuntansi, Prodi. Akuntansi - FEB, UNIPMA, Vol. 1, No.2, April 2018

\begin{tabular}{lll}
\hline misinya adalah berupaya untuk & yang berasal dari golongan \\
mengangkat derajat kaum & menengah ke bawah dan berada di \\
mustad'afin. Konsep ini sejalan & wilayah-wilayah terpencil yang \\
dengan konsep financial inclusion & jauh dari pusat-pusat layanan jasa \\
yang bertujuan untuk meningkatkan & perbankan. Selanjutnya, keberadaan \\
akses pelayanan jasa keuangan & BRILink di wilayah Madiun dan \\
terutama untuk masyarakat kecil & sekitarnya dapat mendukung \\
dan menengah. & program financial inclusion yang \\
Penelitian yang dilakukan & ditetapkan pemerintah.
\end{tabular}

Purwati (2016) tentang Analisis Penerapan BRILink di Bank BRI Martadinata Kota Malang sebagai Upaya Mendorong Financial Inclusion menemukan bahwa layanan BRILink mudah diterima oleh masyarakat. BRILink efektif dalam mengatasi financial inclusion. Program BRILink merupakan salah satu alternatif yang dikemukakan oleh Bank BRI untuk mengatasi hambatan financial inclusion. Program BRILink ini merupakan layanan bank tanpa kantor dengan sistem keagenan dari Bank BRI untuk mendorong financial inclusion .

Keberadaan BRILink di wilayah Madiun dan sekitarnya diharapkan dapat meningkatkan akses masyarakat terhadap sektor perbankan, khususnya masyarakat

\section{KAJIAN PUSTAKA}

Penelitian tentang penerapan BRILinkdan hubungannya dengan financial inclusion ini menggunakan grand theory teori sikap dan perilaku (theory of attitude and behavior) dan teori tentang literasi keuangan yang didukung pula dengan beberapa supporting theory. Teori sikap dan perilaku ini digunakan untuk menjelaskan tentang perilaku masyarakat terkait penggunaan BRILinkPT. BRI (Persero), Tbk., sedangkan teori tentang literasi keuangan (financial literation)untuk menjelaskan keberhasilan penerapan BRILinkdalam mendorong financial inclusion.

\section{Theory of Attitude and Behavior}

Landasan teori yang digunakan dalam penelitian ini adalah theory of 
INVENTORY

Jurnal Akuntansi, Prodi. Akuntansi - FEB, UNIPMA, Vol. 1, No.2, April 2018

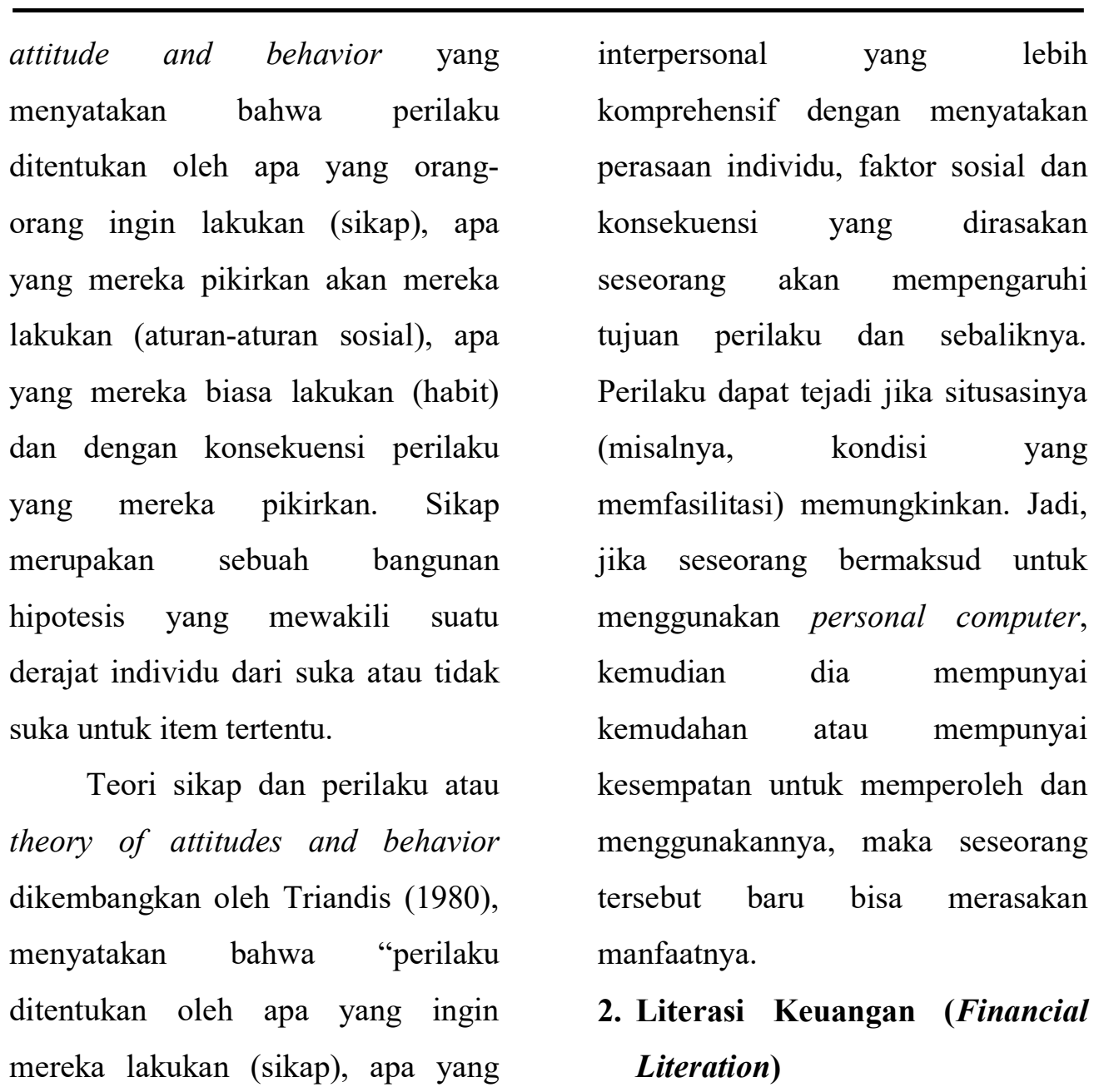

mereka pikirkan akan mereka

lakukan (aturan-aturan sosial), apa

yang mereka biasa lakukan

(kebiasaan) dan konsekuensi perilaku

dari yang mereka pikirkan" (Sunarta,

2005). "Sikap merupakan sebuah

tiang bangunan yang mewakili suatu

gambaran individu mengenai suka

atau tidak suka terhadap sesuatu"

(Amalia, 2010).

Triandis (dalam Sunarta, 2005)

menyajikan suatu model perilaku

Keberhasilan program

financial inclusion atau inklusi keuangan tidak akan dapat tercapai tanpa adanya pengetahuan, keyakinan, dan keterampilan masyarakat yang mempengaruhi sikap dan perilaku untuk meningkatkan kualitas pengambilan keputusan dan pengelolaan keuangan atau yang disebut dengan literasi keuangan. Untuk itu, sebelum menguraikan teori-teori tentang 
INVENTORY

Jurnal Akuntansi, Prodi. Akuntansi - FEB, UNIPMA, Vol. 1, No.2, April 2018

financial inclusion, perlu diuraikan

tentang teori atau konsep dari literasi

keuangan.

a. Konsep Literasi Keuangan

Literasi keuangan (financial literacy) yang artinya melek keuangan, menurut buku podoman Strategi Nasional

Literasi Keuangan Indonesia

(Otoritas Jasa Keuangan, 2014) yang dimaksud dengan literasi keuangan adalah "Rangkaian proses atau aktivitas untuk meningkatkan pengetahuan (knowledge), keyakinan (confidence), dan keterampilan (skill) konsumen dan masyarakat luas sehingga mereka mampu mengelola keuangan yang lebih baik." Berdasarkan pengertian tersebut, dapat disimpulkan bahwa konsumen produk dan jasa keuangan maupun masyarakat luas diharapkan tidak hanya mengetahui dan memahami lembaga jasa keuangan serta produk dan jasa keuangan, melainkan juga dapat mengubah atau memperbaiki perilaku masyarakat dalam pengelolaan keuangan sehingga mampu meningkatkan kesejahteraannya. Literasi keuangan berkaitan dengan kompetensi seseorang untuk mengelola keuangan. Definisi literasi finansial menurut Vitt, dkk. (dalam Huston, 2010) adalah sebagai berikut.

Personal financial literacy is the ability to read, analyze, manage and communicate about the personal financial condition that affect material well-being. It includes the ability to discern financial choices, discuss money and financial issues without (or despite) discomfort, plan

uture and respond competently to life events that affect everyday financial decisions, including events in the general economy.

Literasi finansial terjadi ketika individu memiliki sekumpulan keahlian dan kemampuan yang membuat orang tersebut mampu memanfaatkan sumber daya yang ada untuk mencapai tujuan. Huston (2010) juga menyatakan bahwa pengetahuan finansial merupakan dimensi yang tidak terpisahkan 
dari literasi finansial, namun

belum dapat menggambarkan

literasi finansial.

Definisi dasar literasi keuangan menurut Remund (2010) berhubungan dengan kemampuan seseorang untuk mengelola dananya.

By the most basic definition, financial literacy relates to a person's competency for managing money. The concept has not always been described as financial literacy, but the idea dates to the early 1900 s and the advent of consumer education research and initiatives in the United States (Jelley 1958). Financial literacy is typically measured at the individual level and then aggregated by groups, such as high school students or low-income adults, to provide a macroview.

Konsep ini awalnya tidak dideskripsikan sebagai sebuah literasi keuangan, tetapi gagasan ini ada di awal tahun 1900 bersamaan dengan sebuah penelitian akan pendidikan terhadap konsumen yang ada di
Amerika. Literasi keuangan secara khas diperhitungkan dalam level individual lalu berkembang menjadi kelompok-kelompok, seperti siswa sekolah atau para pegawai yang berpenghasilan rendah, sebagai gambaran ekonomi makro.

Menurut penelitiannya yang dimulai sejak tahun 2000, Remund (2010) menyatakan:

Based upon a review of research studies since 2000, the many conceptual definitions of financial literacy fall into five categories:

(1) knowledge of financial concepts, (2) ability to communicate about financial concepts, (3) aptitude in managing personal finances, (4) skill in making appropriate financial decisions and (5) confidence in planning effectively for future financial need.

Pendapat tersebut menyatakan bahwa lima kategori tentang definisi konseptual mengenai literasi keuangan sebagai berikut: (1) pengetahuan terhadap konsep keuangan, (2) kemampuan untuk berkomunikasi mengenai konsep 
keuangan, (3) ketangkasan dalam

mengelola keuangan pribadi, (4) kemampuan di dalam membuat keputusan keuangan yang tepat, (5) kemampuan dalam merencanakan keuangan masa depan yang efektif sesuai yang dibutuhkan.

Berdasarkan uraian beberapa ahli di atas, dapat disampaikan bahwa literasi keuangan merupakan sebuah langkah atas sebuah tingkatan yang mana dapat memahami konsep dari keuangan dan proses dari sebuah kemampuan untuk mengurus keuangan pribadinya secara tepat, baik dalam jangku waktu pendek, sedang, maupun seumur hidup dan merubah kedaaan ekonominya. Dapat dipahami dari berbagai konsep tersebut, literasi keuangan merupakan sebuah kesadaran pada masyarakat dalam mengelola dana miliknya berdasarkan pengetahuan yang didapatkannya. Sehingga kesadaran tersebut berbuah pada sikap dan tingkah laku yang diharapkan dapat menyejahterakan kehidupan mereka.

b. Tujuan, Visi dan Misi, serta Manfaat Literasi Keuangan Tujuan Literasi Keuangan (OJK, 2016) adalah sebagai berikut:

1) Meningkatkan literasi seseorang yang sebelumnya less/not literate menjadi well literate, dan

2) Meningkatkan jumlah pengguna produk dan jasa keuangan, agar konsumen dan masyarakat luas dapat menentukan produk dan jasa keuangan yang sesuai dengan kebutuhan mereka, memahami dengan benar manfaat dan risikonya, mengetahui hak dan kewajiban serta meyakini bahwa produk dan jasa keuangan yang dipilih tersebut dapat meningkatkan kesejahteraan mereka.

Sedangkan visi literasi keuangan (OJK, 2016) adalah mewujudkan masyarakat Indonesia yang 
memiliki tingkat literasi

keuangan yang tinggi (well

literate) sehingga

masyarakat dapat memilih

dan memanfaatkan produk

dan jasa keuangan guna

meningkatkan

kesejahteraan. Sedangkan, misi literasi keuangan (OJK, 2016) adalah sebagai berikut:

1) Melakukan edukasi di bidang keuangan kepada masyarakat Indonesia agar dapat mengelola keuangan secara cerdas; dan

2) Meningkatkan akses informasi serta penggunaan produk dan jasa keuangan melalui pengembangan

infrastruktur pendukung literasi keuangan.

Terdapat lima prinsip literasi keuangan, yaitu (OJK, 2016):

1) Inklusif, yaitu mencakup semua golongan masyarakat.
2) Sistematis dan terukur, yaitu literasi keuangan disampaikan secara terprogram, mudah dipahami, sederhana, dan pencapaiannya dapat diukur.

3) Kemudahan akses, yaitu layanan dan informasi keuangan tersebar luas di seluruh wilayah Indonesia dan mudah diakses.

4) Kolaborasi, yaitu melibatkan seluruh stakeholders secara bersama-sama dalam mengimplementasikan literasi keuangan.

$\begin{array}{lr}\text { Literasi } & \text { keuangan } \\ \text { telah menjadi } & \text { program } \\ \text { nasional } & \text { untuk } \\ \text { meningkatkan } & \text { kemakmuran } \\ \text { dan } & \text { kesejahteraan } \\ \text { masyarakatnyar } & \text { Menurut }\end{array}$
OJK (2016) literasi keuangan memiliki berbagai manfaat bagi:

1) Masyarakat 
a) Mampu memilih dan memanfaatkan produk jasa keuangan

b) Memiliki kemampuan dalam melakukan perencanaan keuangan dengan lebih baik

c) Terhindar dari aktivitas investasi pada instrumen keuangan yang tidak jelas, dan

d) Mendapatkan

pemahaman mengenai manfaat dan risiko produk dan jasa keuangan.

2) Industri Keuangan

a) $\mathrm{Ser}$ potensi transaksi keuangan yang dilakukan masyarakat sehingga potensi keuangan yang diperoleh lembaga jasa keuangan (LJK) semakin besar.

b) Memotivasi LJK mengembangkan produk dan layanan sesuai dengan kebutuhan masyarakat.

3) Ekonomi Makro

a) Semakin banyak masyarakat yang well literate semakin banyak jumlah pengguna produk dan jasa keuangan sehingga pada akhirnya akan menciptakan pemerataan kesejahteraan.

b) Semakin banyak yang menabung dan berinvestasi diharapkan sumber dana untuk pembangunan semakin meningkat.

c) Semakin banyak orang yang memanfaatkan dana lembaga jasa keuangan, intermediasi di sektor jasa keuangan diharapkan semakin besar. 
c. Faktor-faktoryang

Mempengaruhi Literasi

\section{Keuangan}

Pada dasarnya tingkat literasi keuangan yang dimiliki masing-masing individu berbeda-beda. Hal tersebut disebabkan oleh perbedaan faktor yang mempengaruhinya sehingga terjadi perbedaan yang signifikan antara individu satu dengan yang lain. Dalam penelitiannya Monticone (2010) dan Huston (2010) menjelaskan bahwa tingkat literasi keuangan seseorang dipengaruhi oleh:

1) Karakteristik Sosiodemografi

Dalam hal ini dikatakan bahwa perempuan dan etnis minoritas memiliki pengetahuan keuangan yang rendah, dan lakilaki memiliki pengetahuan keuangan dan ekonomi makro yang baik. Hal tersebut disebabkan oleh tinggi rendahnya pendidikan yang di tempuh, akan tetapi selain pendidikan formal, kemampuan kognitif memiliki peran untuk meningkatkan pengetahuan keuangan. Jadi pada intinya, faktorfaktor yang terdapat dalam demografi yaitu meliputi etnis, gender dan kemampaun kognitif.

2) Latar Belakang Keluarga Selain sosio-demografi dan kemampuan kognitif, literasi keuangan juga dilatar belakangi oleh keluarga seperti pendidikan orang tua terutama ibu. Jadi pendidikan yang diperoleh dari orang tua atau keluarga dapat mempengaruhi

pengetahuan keuangan seseorang.

3) Kekayaan

Pengetahuan keuangan merupakan modal penting manusia untuk berinvestasi jangka 


$$
\begin{aligned}
& \text { panjang dan merupakan } \\
& \text { bekal untuk menjalankan } \\
& \text { kehidupanya di masa } \\
& \text { sekarang dan masa yang } \\
& \text { akan datang, } \\
& \text { pengetahuan keuangan } \\
& \text { sangat dibutuhkan oleh } \\
& \text { investor guna } \\
& \text { memperoleh tingkat } \\
& \text { income yang lebih tinggi. } \\
& \text { Oleh karena itu setiap } \\
& \text { individu yang memiliki } \\
& \text { kekayaan yang memadai } \\
& \text { harus memiliki dan } \\
& \text { menguasai pengetahuan } \\
& \text { keuangan agar dapat } \\
& \text { mengelola kekayaanya } \\
& \text { dengan baik dan seefisien } \\
& \text { mungkin. }
\end{aligned}
$$

4) Preferensi Waktu

Huston

mengatakan bahwa ada beberapa faktor yang dapat mempengaruhi kebiasaan finansial (financial behavior) seperti kegiatan ekonomi, keluarga, teman, kemampuan kognitif individu, kebiasaan, komunitas dan institusi.
Berdasarkan

penjelasaan di atas dapat disimpulkan bahwa literasi dapat dipengaruhi oleh beberapa faktor baik itu interal maupun eksternal.

\section{Financial}

\section{Inclusion}

\section{(Keuangan Inklusif)}

a. Pengertian

Financial

Inclusion

(keuangan

inklusif)

Gerdeva dan Rhyne (2011) mendefinisikan inklusi keuangan sebagai sebuah kondisi dimana semua orang dapat mengakses jasa keuangan berkualitas, tersedia dengan harga terjangkau, dengan cara yang nyaman dan memuaskan. Sarma (2012) mendefinisikan inklusi keuangan sebagai sebuah proses yang menjamin kemudahan dalam akses, ketersediaan, dan manfaat dari sistem keuangan formal bagi seluruh pelaku ekonomi. 


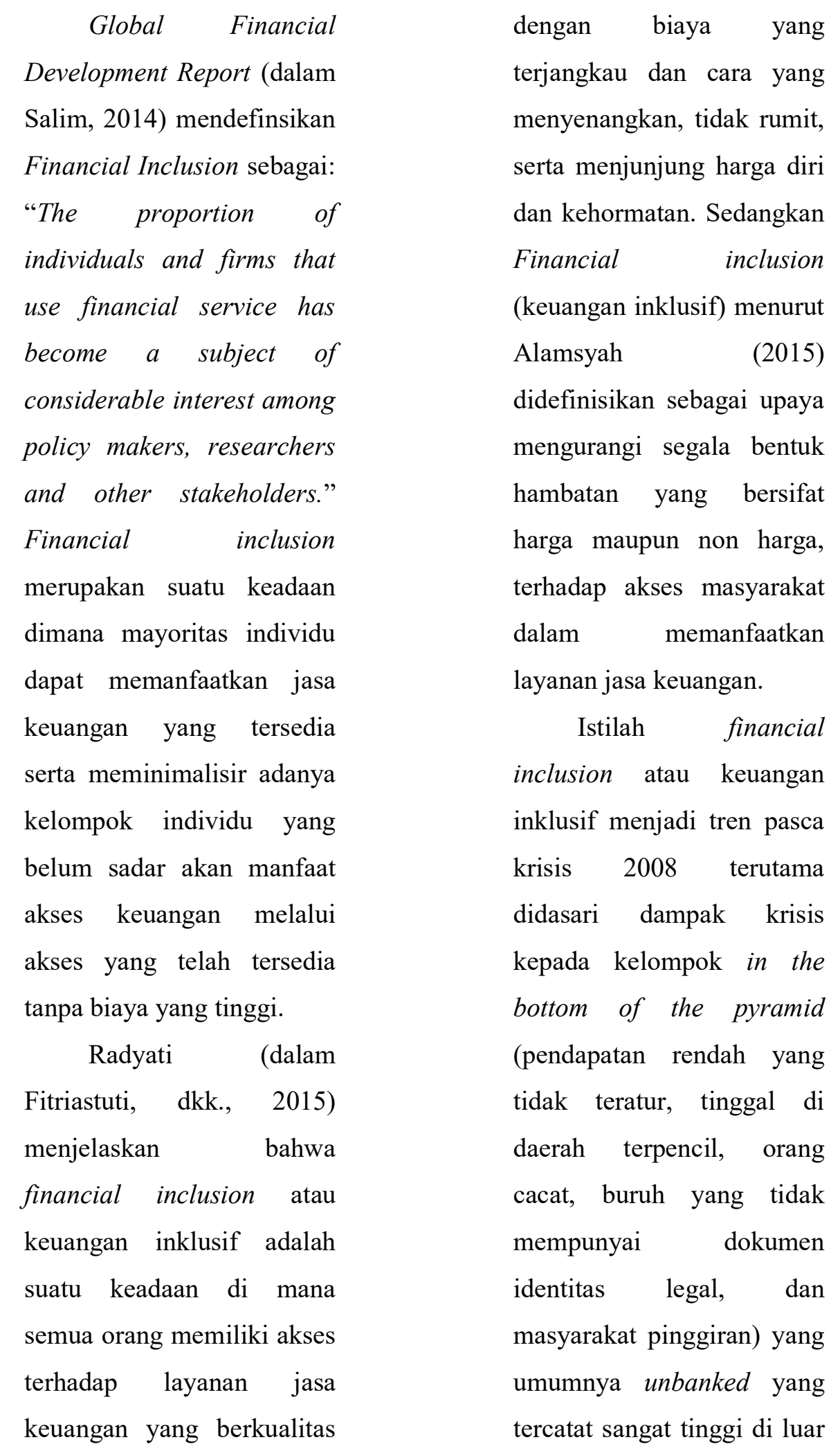


Negara maju (Bank

Indonesia, 2016). Menurut

Peraturan Otoritas Jasa

Keuangan Nomor

7/POJK.07/2016, inklusi

keuangan adalah

ketersediaan akses bagi

masyarakat untuk

memanfaatkan produk

dan/atau layanan jasa

keuangan di lembaga jasa

keuangan sesuai dengan

kebutuhan dan kemampuan

masyarakat dalam rangka

mewujudkan kesejahteraan.

Pada dasarnya,

kebijakan keuangan inklusif

adalah suatu bentuk

pendalaman layanan

keuangan (financial service

deepening) yang ditujukan

kepada masyarakat in the

bottom of the pyramid untuk

memanfaatkan produk dan

jasa keuangan formal seperti

sarana menyimpan uang

yang aman (keeping),

transfer, menabung maupun

pinjaman dan asuransi. Hal

ini dilakukan tidak saja

menyediakan produk dengan cara yang sesuai tapi

dikombinasikan dengan

berbagai aspek Strategi

keuangan inklusif bukanlah

sebuah inisiatif yang

terisolasi. Sehingga

keterlibatan dalam

keuangan inklusif tidak

hanya terkait dengan tugas

Bank Indonesia, namun juga

regulator, kementerian dan

lembaga lainnya dalam

upaya pelayanan keuangan

kepada masyarakat luas.

Melalui strategi nasional

keuangan inklusif

diharapkan kolaborasi antar

lembaga pemerintah dan

pemangku kepentingan

tercipta secara baik dan terstruktur.

b. Visi dan Tujuan Financial

Inclusion

(Keuangan

Inklusif)

Visi

nasional

Financial

Inclusion

(keuangan

inklusif)

dirumuskan

untuk

mewujudkan sistem

keuangan yang dapat

diakses oleh seluruh lapisan 
masyarakat
mendorong pertumbuhan
ekonomi, penanggulangan
kemiskinan, pemerataan
pendapatan, dan terciptanya
stabilitas sistem keuangan di
Indonesia. Menurut Bank
Indonesia (2014) visi
nasional keuangan inklusif
dirumuskan sebagai berikut:
"mewujudkan sistem
keuangan yang dapat
diakses oleh seluruh lapisan
masyarakat
mendorong pertumbuhan
ekonomi, penanggulangan
kemiskinan, pemerataan
pendapatan dan terciptanya
stabilitas sistem keuangan di
Indonesia."

Visi keuangan inklusif tersebut dijabarkan dalam beberapa tujuan sebagai berikut (Bank Indonesia, 2014):

1) Tujuan 1: Menjadikan strategi keuangan inklusif sebagai bagian dari strategi besar pembangunan ekonomi, penanggulangan kemiskinan, pemerataan pendapatan dan stabilitas sistem keuangan. Keuangan inklusif adalah strategi untuk mencapai tujuan pembangunan ekonomi yang lebih luas, yaitu penanggulangan kemiskinan dan peningkatan kesejahteraan masyarakat, serta bagian dari strategi untuk mencapai stabilitas sistem keuangan. Kelompok miskin dan marjinal merupakan kelompok yang memiliki keterbatasan akses ke layanan keuangan. Tujuan keuangan inklusif adalah memberikan akses ke jasa keuangan yang lebih luas bagi setiap penduduk, namun terdapat kebutuhan untuk memberikan fokus lebih besar kepada penduduk miskin.

2) Tujuan 2: Menyediakan jasa dan produk 


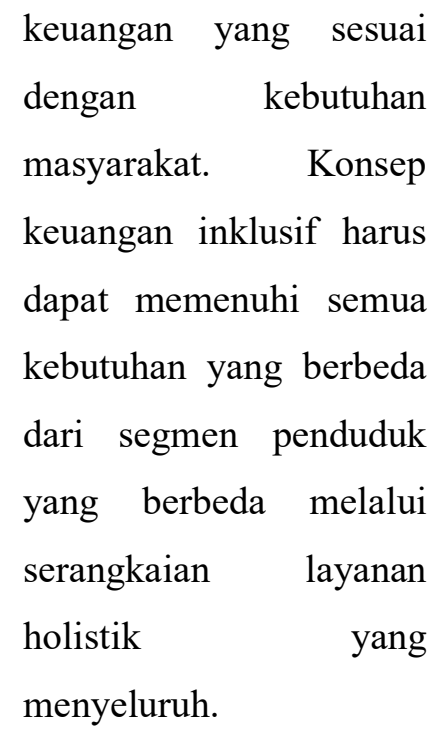

3) Tujuan 3: Meningkatkan pengetahuan masyarakat mengenai layanan keuangan. Hambatan utama dalam keuangan inklusif adalah tingkat pengetahuan keuangan yang rendah. Pengetahuan ini penting agar masyarakat merasa lebih aman berinteraksi dengan lembaga keuangan.

4) Tujuan 4: Meningkatkan akses masyarakat ke layanan keuangan. Hambatan bagi orang miskin untuk mengakses layanan keuangan umumnya berupa masalah geografis dan kendala administrasi. Menyelesaikan permasalahan tersebut akan menjadi terobosan mendasar dalam menyederhanakan akses ke jasa keuangan.

5) Tujuan 5: Memperkuat sinergi antara bank, lembaga keuangan mikro, dan lembaga keuangan non bank. Pemerintah harus menjamin tidak hanya pemberdayaan kantor cabang, tetapi juga peraturan yang memungkinkan perluasan layanan keuangan formal. Oleh karena itu, sinergi antara Bank, Lembaga Keuangan Mikro (LKM) dan Lembaga Keuangan Bukan Bank menjadi penting khususnya dalam mendukung pencapaian stabilitas sistem keuangan. 


\begin{tabular}{|c|c|}
\hline 6) Tujuan & 1) Sasaran \\
\hline Mengoptimalkan peran & Keuangan Inklusif \\
\hline teknologi informasi dan & Keuangan inklusif ini \\
\hline komunikasi (TIK) untuk & merupakan \\
\hline memperluas cakupan & pembangunan \\
\hline keuangan. & mendorong \\
\hline Teknologi & pertumbuhan ekonomi \\
\hline mengurangi & pemerataan \\
\hline transaksi & pendapatan, pengentasan \\
\hline memperluas & kemiskinan \\
\hline keuangan & stabilitas \\
\hline melampaui & keuangan. Strategi yang \\
\hline layanan tabungan dan & berpusat \\
\hline kredit. Namun, pedoman & masyarakat ini perlu \\
\hline dan peraturan yang jelas & menyasar kelompok yang \\
\hline perlu ditetapkan untuk & mengalami \\
\hline menyeimbangkan & untuk mengakses layanan \\
\hline perluasan jangkauan dan & keuangan. \\
\hline resikonya. & Pengelompokan kategori \\
\hline c. Strategi Nasional Financial & miskin: \\
\hline Inclusion & a) Termiskin dari yang \\
\hline Menurut & miskin \\
\hline Indonesia (2014), financial & Penduduk \\
\hline inclusion telah menjadi & yang tidak memiliki \\
\hline suatu bentuk & pendapatan \\
\hline pemerintah & karena berbagai faktor \\
\hline Indonesia. Adapun Strategi & seperti sakit, cacat \\
\hline Nasional Keungan Inklusif & fisik sehingga tidak \\
\hline tersebut dapat dijabarkan & memiliki pendapatan. \\
\hline sebagai berikut. & b) Miskin berpendapatan \\
\hline & rendah \\
\hline
\end{tabular}


Mereka yang memiliki

akses sangat terbatas

atau tanpa akses sama

sekali ke semua jenis

layanan keuangan.

Termasuk kelompok

miskin yang bekerja

sebagai buruh dengan

penghasilan sangat

terbatas dan bersifat

tidak tetap atau

musiman yang pada

umumnya bekerja di

sektor pertanian atau

sektor-sektor lainnya

yang bersifat padat

karya.

c) Miskin bekerja

Kelompok penduduk

miskin yang

berpenghasilan relatif

cukup untuk

memenuhi kebutuhan

hidup dasar dengan

bekerja di sektor

informal.

d) Bukan miskin

Kategori ini meliputi

semua penduduk yang

tidak memenuhi

criteria untuk masuk dalam kelompok

masyarakat miskin

berpendapatan

terendah dan miskin

bekerja.

e) Pekerja migrant

domestik dan

internasional

Indonesia merupakan

Negara penerima

remitansi ketiga

terbesar di wilayah

asia-pasifik. Sekitar

80 persen pekerja migran atau lazim

disebut TKI (Tenaga

Kerja Indonesia)

adalah perempuan dan

lebih dari 85 persen

bekerja di sektor

informal. TKI

biasanya kurang

terlayani oleh sektor

keuangan, atau

memiliki akses yang

terbatas ke layanan

keuangan. Mereka

terutama

membutuhkan sarana

untuk mengirim uang

secara aman, cepat, 
dan murah dari tempat

kerja ke rumah, yang sering kali terletak di daerah terpencil dan tertinggal. TKI umumnya berasal dari rumah tangga pertanian yang miskin, yang terletak di daerah pedesaan dengan tingkat pendapatan rendah.

f) Perempuan

Di banyak Negara
berkembang, kerap
terdapat perbedaan
besar antara laki-laki
dan perempuan dalam
hal akses, kebutuhan,
dan pilihan mereka
terhadap jasa
keuangan. Sehingga
dalam
mengembangkan akses terhadap layanan keuangan adalah penting untuk mengenali perbedaanperbedaan tersebut. Di Indonesia, laki-laki dan perempuan miliki kesempatan yang sama untuk mempunyai rekening tabungan. Namun, motivasi utama lakilaki saat membuka rekening tabungan bank lebih sering adalah untuk memperoleh kredit, sedangkan perempuan menabung demi keperluan mendatang. Dalam hal kepemilikan asuransi, perempuan lebih sering membeli asuransi pendidikan, sementara laki-laki lebih memilih asuransi jiwa, dan pada taraf tertentu juga memiliki asuransi harta benda.

g) Penduduk daerah terpencil

Sekitar 52 persen penduduk Indonesia hidup di daerah perdesaan dan sekitar 60 persennya tidak memiliki akses ke jasa 
keuangan formal. Dari

sekitar 12,49 persen

penduduk yang berada

di bawah garis

kemiskinan, sekitar 64

persen tinggal di

daerah pedesaan.

Angka-angka ini

ditambah dengan

kondisi sebaran

geografis dari

kepulauan Indonesia,

menunjukkan

pentingnya bagi

strategi nasional

keuangan inklusif

untuk member

perhatian khusus

kepada masyarakat di

daerah-daerah

terpencil.

Kesenjangan akses ke

jasa keuangan untuk

kategori ini sebagian

dapat diatasi dengan

penggunaan teknologi

informasi dan

komunikasi.

d. Kerangka keuangan inklusif

Menurut Bank

Indonesia (2014) kerangka kerja umum keuangan

inklusif dibangun di atas

enam pilar sebagai berikut:

1) Edukasi keuangan.

Bertujuan meningkatkan

pengetahuan dan

kesadaran masyarakat

luas tentang produk-

produk dan jasa-jasa

keuangan yang ada

dalam pasar keuangan

formal. Ruang lingkup

edukasi keuangan ini

meliputi: a) pengetahuan

dan kesadaran tentang

ragam produk dan jasa

keuangan,

b)

pengetahuan dan

kesadaran tentang risiko terkait dengan produk keuangan,

perlindungan nasabah, d) ketrampilan mengelola keuangan.

2) Fasilitas keuangan publik. Strategi pada pilar ini mengacu pada kemampuan dan peran pemerintah dalam menyediakan

pembiayaan keuangan 


\begin{tabular}{|c|c|}
\hline publik baik secara & jaminan alternatif, \\
\hline langsung & penyediaan \\
\hline bersyarat & kredit \\
\hline mendorong & sederhana, d) identifikasi \\
\hline pemberdayaan ekonomi & nasabah potensial. \\
\hline masyarakat. & 4) Kebijakan atau peraturan \\
\hline inisiatif dalam pilar ini & yang mendukung. $\mathrm{Pi}$ \\
\hline meliputi: a) subsidi dan & mengacu \\
\hline bantuan sosial, b) & kebutuhan \\
\hline pemberdayaan & menambah \\
\hline masyarakat, & memodifikasi peraturan, \\
\hline pemberdayaan UMKM. & baik oleh pemerintah \\
\hline Pemetaan & untuk \\
\hline keuangan. & meningkatkan akses a \\
\hline meningkatkan & jasa keuangan. Pilar \\
\hline kapasitas masyarakat & meliputi beberapa aspek: \\
\hline terutama & a) kebijakan mendorong \\
\hline sebenarnya dikategorikan & sosialisasi produk ja \\
\hline tidak layak untuk & keuangan yang sesuai \\
\hline menjadi layak atau dari & kebutuhan \\
\hline unbankable & masyarakat, \\
\hline bankable oleh institusi & menyusun skema produk \\
\hline keuangan & yang sesuai \\
\hline terutama kaum miskin & kebutuhan masyarakat, c) \\
\hline produktif serta serta & mendororng perubahan \\
\hline usaha mikro & ketentuan dengan tetap \\
\hline Inisiatif & memperhatikan \\
\hline meliputi: a) peningkatan & kehati-hatian \\
\hline kapasitas & proporsional, \\
\hline penyediaan pelatihan dan & menyusun \\
\hline bantuan teknis, b) sistem & mekanisme \\
\hline
\end{tabular}




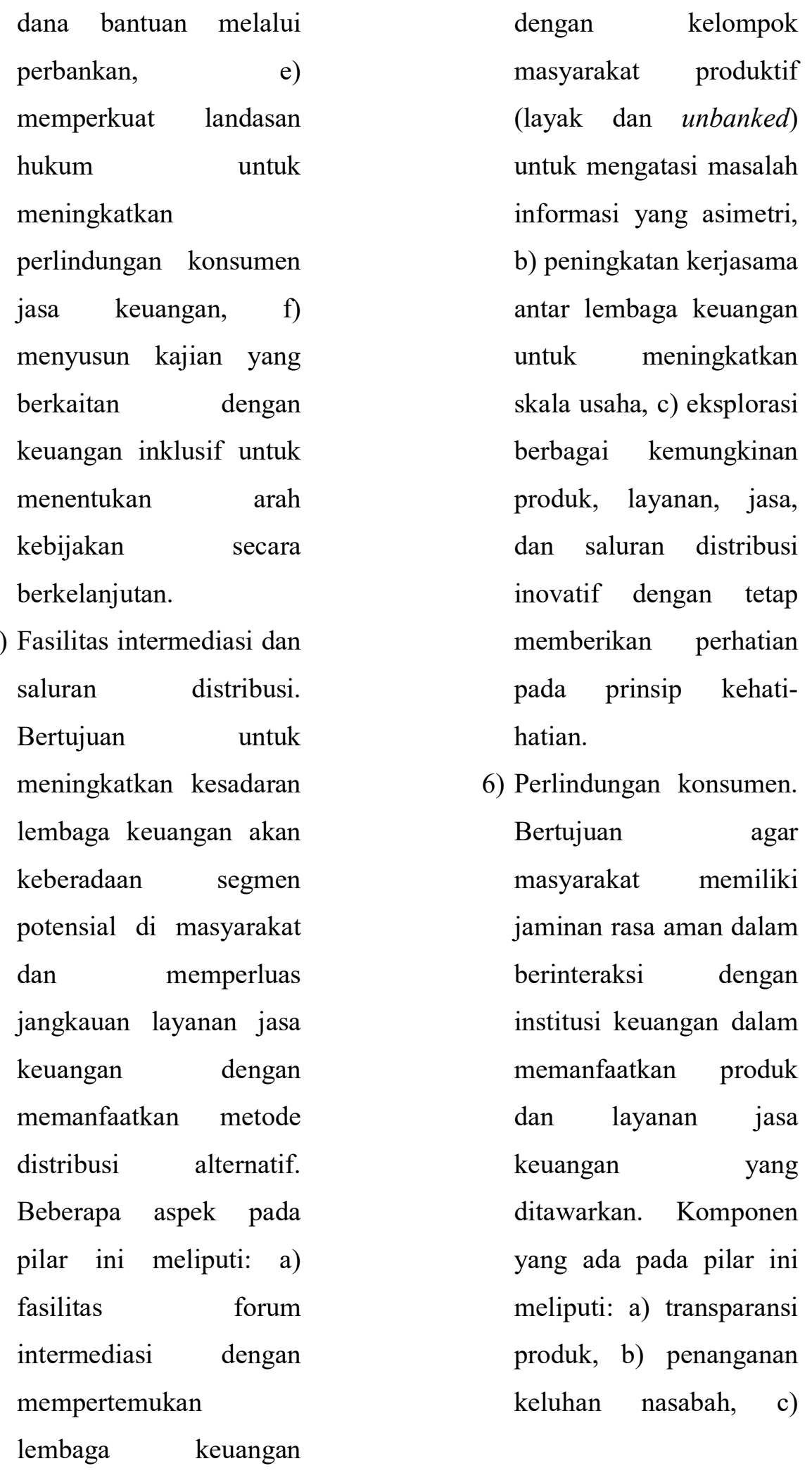




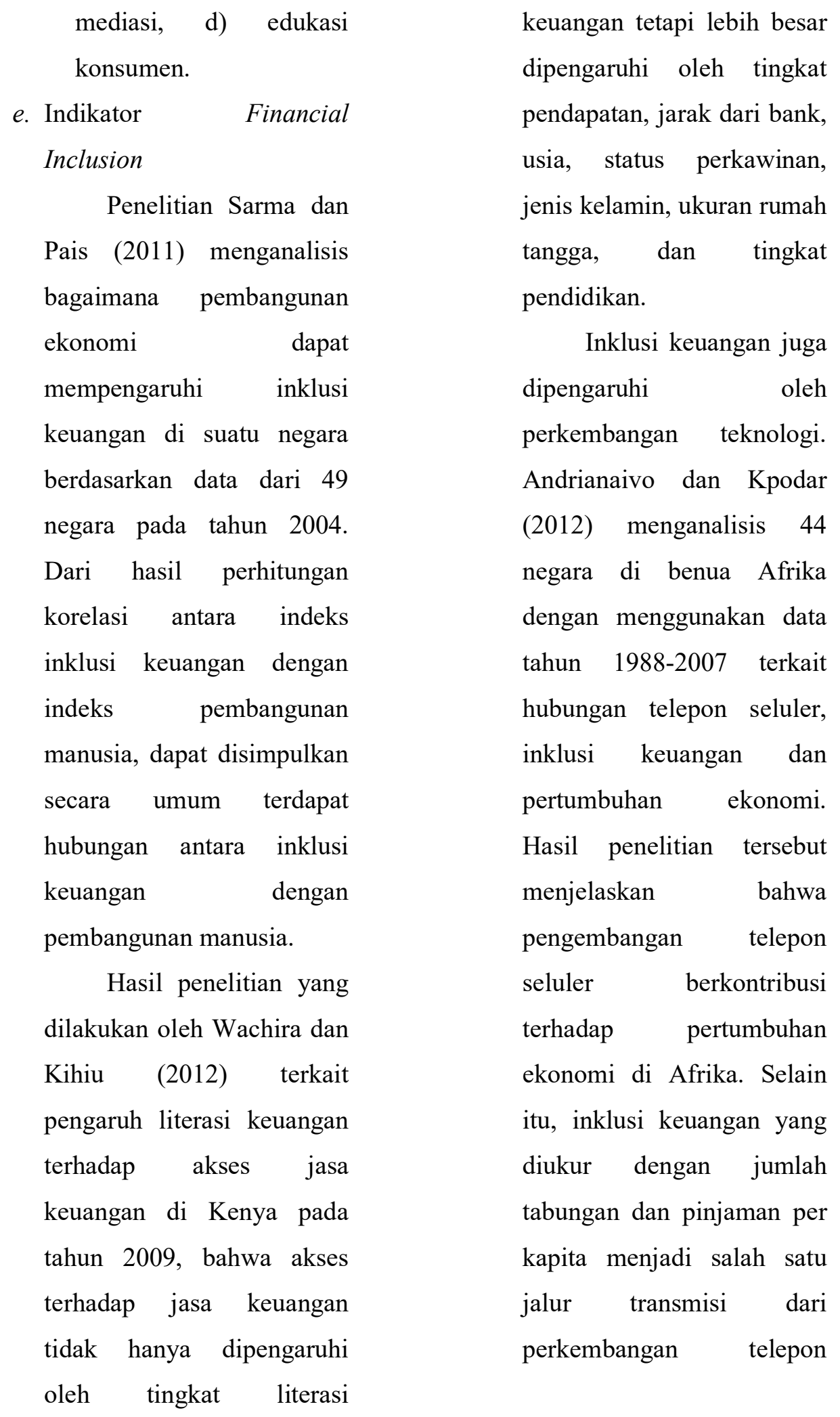


seluler
pertumbuhan.

Menurut Salma (2012) pentingnya keuangan inklusif telah diakui secara luas, namun literatur tentang keuangan inklusif belum banyak yang mengcover secara komperhensif sejauhmana tingkat keuangan inklusif di seluruh negara. Beberepa indikator inklusi keuangan yang paling sering digunakan oleh orang-orang yang berbeda.

While the importance of financial inclusion has been widely recognised, the literature on financial inclusion lacks a comprehensive measure that can be used to measure the extent of financial inclusion across economies. Several indicators have been used to indicate the extent of financial inclusion by different people. The most commonly used indicator has been the number of bank accounts (per 100 adult persons). Some other indicators are number of bank branches (per million people), number of ATMs (per million people), amount of bank credit and amount of bank deposit. Such indicators, while used individually, can provide only partial information on the inclusiveness of the financial system of an economy.

Indikator yang paling sering digunakan adalah penggunaan akun bank (per 100 orang dewasa). Beberapa yang lain menggunakan jaringan distribusi layanan keuangan (branchless banking) (per satu juta jiwa), pemilikan ATM (per satu juta jiwa), jumlah kredit (pembiayaan) dan jumlah deposito. Beberapa indikator, ketika digunakan secara individual hanya dapat menyediakan informasi secara parsial 
terhadap tingkat inklusi

keuangan.

Menurut

Bank

Indonesia (2014), indikator keuangan inklusif yang digunakan oleh Bank Indonesia adalah sebagai berikut:

a. Ketersediaan/akses, yaitu mengukur kemampuan penggunaan jasa keuangan formal dalam hal keterjangkauan fisik dan harga.

b. Penggunaan, yaitu mengukur kemampuan penggunaan aktual produk dan jasa keuangan (antara lain: keteraturan, frekuensi dan lama penggunaan).

c. Kualitas, yaitu mengukur apakah atribut produk dan jasa keuangan telah memenuhi kebutuhan pelanggan.

d. Kesejahteraan, yaitu mengukur dampak layanan keuangan terhadap tingkat kehidupan pengguna jasa.

\section{METODE}

Penelitian ini menggunakan pendekatan kualitatif. Bogdan dan Taylor (Moleong, 2012) mendefinisikan pendekatan kualitatif sebagai prosedur penelitian yang menghasilkan data deskriptif berupa kata-kata tertulis atau lisan dari orang-orang dan perilaku yang dapat diamati.Jenis penelitian ini merupakan penelitian deskriptif kualitatif, yaitu penelitian yang terbatas pada usaha-usaha yang mengungkapkan suatu masalah atau keadaan atau peristiwa sebagaimana adanya sehingga bersifat sekedar mengungkapkan fakta (fact finding). Metode penelitian kualitatif adalah metode penelitian yang digunakan untuk meneliti pada kondisi obyek yang alamiah dimana peneliti adalah sebagai instrumen kunci, analisis data bersifat induktif/kualitatif, dan hasil penelitian kualitatif lebih 
INVENTORY

Jurnal Akuntansi, Prodi. Akuntansi - FEB, UNIPMA, Vol. 1, No.2, April 2018

menekankan makna daripada

generalisasi.

1. Tempat Penelitian

Penelitian

ini

dilaksanakan di PT. BRI

(Persero), Tbk. Kantor Cabang

Madiun yang beralamat di

Jalan Pahlawan, Nomor 50.

Kota Madiun. Penetapan

tempat penelitian ini dengan

mempertimbangkan beberapa

hal sebagai berikut:

a. Adanya realita yang menunjukkan semakin meningkatnya jumlah agen BRILink PT. BRI (Persero), Tbk. Kantor Cabang Madiun untuk wilayah madiun dan sekitarnya.

b. Pentingnya mendukung program financial inclusion yang ditetapkan pemerintah melalui layanan branchless banking.

c. Peran penting layanan BRILink dalam rangka mendukung program financial inclusion.
HASIL DAN PEMBAHASAN

BRILink adalah salah satu konsep perluasan delivery channel BRI yang diharapkan dapat meningkatkan transaksi dan pelayanan kepada nasabah. Dengan konsep kerjasama berupa pemanfaatan biller BRI oleh agen BRILink, baik melalui sistem BRI atau sistem agen (pihak ketiga) BRILink dengan konsep sharing fee yang disepakati. Diharapkan, BRILink dapat meningkatkan pelayanan perbankan bagi nasabah maupun masyarakat melalui outlet dari rekanan BRI. Media atau perangkat untuk pelaksanaan transaksi BRILink yang digunakan adalah Electronic Data Capture (EDC) (Nota Dinas BRI No. B.961LYN/KPO/11/2013). BRILink adalah perluasan layanan BRI dimana BRI menjalin kerjasama dengan nasabah BRI sebagai Agen yang dapat melayani transaksi perbankan bagi masyarakat secara real timeonline menggunakan fitur EDC mini ATM BRI dengan 
konsep sharing fee (BRI,

www.bri.co.id.,

2017).Berdasarkan permasalahan

dalam penelitian ini maka

disusun sebagai berikut :

1. Keberlangsungan layanan

BRILink pada PT. BRI (Persero), Tbk. Kantor

Cabang Madiun di wilayah

Madiun dan sekitarnya.

Mengacu pada tujuan Tujuan

penyelenggaraanBRILink

adalah (BRI, www.bri.co.id., 2017):

a. Menghimpun dana murah melalui rekening dana agen.

b. Meningkatkan fee based income dengan peningkatan perangkat BRI atau utilitas EDC BRI.

c. Mengurangi cost of transaction BRI dengan mengalihkan transaksi yang ada di unit kerja BRI ke e-channel BRI.

d. Memberikan kemudahan, kenyamanan, kecepatan dan keamanan bagi nasabah dalam melakukan transaksi perbankan baik bagi nasabah yang telah memiliki nomor rekening maupun yang belum memiliki nomor rekening.

e. Memperluas jaringan mikro dan menambah jumlah nasabah (customer based).

Sesuai dengan temuan dilapangan bahwa bahwa gambaran keberlangsungan layanan BRILink pada PT. BRI (Persero), Tbk. Kantor Cabang Madiun cukup baik ,hal ini dibuktikan dengan:

1) Semakin bertambahnya jumlah agen yang menggunakan BRIlink dengan mesin EDC ,kemudahan transaksi dalam penggunaan nya mampu meningkatkan kenyamanan, kecepatan dan keamanan bagi nasabah dalam melakukan transaksi perbankan baik bagi nasabah yang telah memiliki nomor rekening maupun yang belum memiliki nomor rekening. 
2) Cepat dan hemat waktu. Banyak nasabah bank, khususnya nasabah bank BRI yang mengeluh karena harus mengantri berjam-jam ketika akan melakukan transaksi. Transaksi di agen BRILink bisa dilakukan dengan cepat dan mudah karena nasabah Agen BRILink tidak terlalu banyak jadi tidak perlu mengantri. Karena itu bisa menghemat waktu nasabah. Pelayanannya juga pasti lebih cepat. Apalagi jika transaksi dilayani langsung oleh Agen (bukan pegawai).

3) Bisa melakukan transaksi kapan saja tidak terikat jam kantor. Pada dasarnya, jam kerja agen BRILink ditentukan oleh agen itu sendiri.

4) Bisa Tarik uang, bukan Cuma setor/transfer, tarik uang pun bisa, dengan menggunakan ATM, baik itu ATM BRI ataupun ATM bank lain yang berlogo Link, Prima dan ATM Bersama.
5) Bukan hanya transfer, nabung, tarik tunai, dan cek saldo, tapi juga bisa melakukan transaksi lain seperti isi ulang pulsa, bayar listrik, beli token listril, cicilan bank, kartu kredit, dll.

2. Hambatan-hambatan yang ada pada penerapan BRILinkPT. BRI (Persero), Tbk. Kantor Cabang Madiun di wilayah Madiun dan sekitarnya.

Penerapan BRILinkPT. BRI (Persero), Tbk. Kantor Cabang Madiun di wilayah Madiun dan sekitarnya banyak mengalami hambatan dalam penerapanya hal ini dibuktikan dengan:

a) Karena lokasi Agen BRILink jauh dari kota,daerah yang sulit dijangkau dimana mesin ATM tidak ada,sangat menyulitkan Pegawai Bank BRI untuk Maitanance alat dan pemantauan layanan serta memfollowup layanan.

b) Banyak terjadi kesalahan dalam input data dikarenakan pemilik toko belum mempunyai 


\begin{tabular}{|c|c|}
\hline pengetahuan tentang alat & penggunaanya \\
\hline $\begin{array}{l}\text { EDCdan tidak paham } \\
\text { tekhnologi. }\end{array}$ & $\begin{array}{l}\text { banyak yang belum } \\
\text { menguasai }\end{array}$ \\
\hline rendahnya & tekhnologinya.,serta selalu \\
\hline kesadaran & mengevaluasi \\
\hline tentang layanan perbankan & yang menangani BRIlink \\
\hline atau yang dikenal dengan & penggunaanya \\
\hline literasi keuangan. & bisa maksimal,serta bila \\
\hline Tidak mudah menyakinkan & ada keluhan dari agen bisa \\
\hline pedagang dan pelanggan & segera ditanggapi \\
\hline
\end{tabular}
lainnya,karena nasabah tidak mendapatkan buku tabungan.

e) Resiko terhadap rawan kejahatan karena si agen akan banyak menerima uang dari banyak transaksi. Dari banyaknya hambatan dalam penerapan BRILinkPT. BRI (Persero), Tbk. Kantor Cabang Madiun di wilayah Madiun dan sekitarnya maka PT. BRI (Persero), Tbk. Kantor Cabang Madiun di wilayah Madiun harus selalu memaintance agen serta sering mengadakan pelatihan khususnya pelatihan mesin EDC yang banyak mengalami keluhan
3. Keberhasilan penerapan BRILinkPT. BRI (Persero), Tbk. Kantor Cabang Madiun dalam mendorong financial inclusion di wilayah Madiun dan sekitarnya.

$$
\begin{aligned}
& \text { Layanan } r \text { produk } \\
& \text { BRILink ini merupakan } \\
& \text { bagian dari dukungan BRI } \\
& \text { pada program Pemerintah } \\
& \text { yakni financial inclusion. } \\
& \text { Program ini adalah salah satu } \\
& \text { terobosan BRI untuk } \\
& \text { mengedukasi masyarakat } \\
& \text { Indonesia, dalam mengenal } \\
& \text { pengetahuan dasar tentang } \\
& \text { pengelolaan keuangan } \\
& \text { melalui pemanfaatan produk } \\
& \text { dan layanan perbankan. } \\
& \text { Melalui BRILink, BRI }
\end{aligned}
$$


menyediakan layanan

keuangan nirkantor hingga ke pelosok desa dan wilayah perbatasan. BRILink tidak hanya memberikan manfaat efisiensi operasional, namun juga memberikan kemudahan dalam bertransaksi masyarakat, baik yang sudah menjadi nasabah BRI maupun yang belum menjadi nasabah BRI.

Pemerintah dan Bank Indonesia telah menyiapkan berbagai kegiatan Menurut Bank Indonesia (2014), indikator keuangan inklusif yang digunakan oleh Bank Indonesia adalah sebagai berikut:

a. Ketersediaan/akses, yaitu mengukur kemampuan penggunaan jasa keuangan formal dalam hal keterjangkauan fisik dan harga. keadaannya bahwa akses agen BRIlink pada PT. BRI (Persero), Tbk. Kantor Cabang Madiun jauh dari kota dan sulit untuk dijangkau dimana mesin

ATM tidak ada,sangat menyulitkan Pegawai Bank BRI untuk Maitanance alat dan pemantauan, maka peneliti menyarankan agar dibuat jadwal kunjungan dan evaluasi masing masing agen untuk diketahui penyebab dan kendala di lapangan.

b. Penggunaan, yaitu mengukur kemampuan penggunaan aktual produk dan jasa keuangan (antara lain: keteraturan, frekuensi dan lama penggunaan).Sebagai salah satu Bank BUMN, PT Bank Rakyat Indonesia (Persero) Tbk (BRI) memiliki mimpi besar untuk meningkatkan jumlah UMKM melalui digitalisasi. Hal itu seiring komitmennya untuk mendukung dan menyukseskan program keuangan inklusif yang digagas oleh Bank Indonesia (BI) dan Otoritas Jasa Keuangan (OJK) melalui Layanan Keuangan Digital 
(LKD) dan Layanan Keuangan

Tanpa Kantor dalam Rangka Keuangan Inklusif (Laku

Pandai) dengan menggunakan mesin EDC maka pedagang ataupun nasabah tidak perlu pergi ke Bank tapi langsung ke agen BRIlink. Pemilik toko pengguna BRIlink kenyataan yang ada dilapangan sangat kesulitan dalam input data dikarenakan tidak paham tekhnologi

c. Kualitas, yaitu mengukur apakah atribut produk dan jasa keuangan telah memenuhi kebutuhan pelanggan.

Program BRILink merupakan salah satu layanan tanpa kantor (branchless) yang dikeluarkan oleh PT Bank Rakyat Indonesia Tbkdimana BRI bekerja sama dengan pihak ketiga (agen)untuk melayani berbagai layanan perbankan bagi masyarakat ,baik nasabah BRI maupun non-nasabah BRI,hamper semua transaksi perbankan bisa dilakukan di BRIlink,sehingga masyarakat yang sibuk dan tidak mau ngatri di Bank sangat terbantu dengan BRIlink ini secara langsung maka nasabah dan agen dapat meningkatkan kualitas hidupnya

d. Kesejahteraan, yaitu mengukur dampak layanan keuangan terhadap tingkat kehidupan pengguna jasa.

\section{PENUTUP}

\section{Kesimpulan}

Dari hasil penelitian yang dilakukanBRILink pada PT. BRI (Persero), Tbk. Kantor Cabang Madiun di wilayah Madiun maka peneliti mengambil kesimpulan bahwa

1. Keberlangsungan layanan BRILink pada PT. BRI (Persero), Tbk. Kantor Cabang Madiun di wilayah Madiun dan sekitarnya Mengacu pada tujuan Tujuan penyelenggaraan BRILink adalah (BRI, www.bri.co.id., 2017):

a. Menghimpun dana murah melalui rekening dana agen.

b. Meningkatkan fee based income dengan peningkatan perangkat BRI atau utilitas EDC BRI. 
c. Mengurangi cost of transaction BRI dengan mengalihkan transaksi yang ada di unit kerja BRI ke echannel BRI.

d. Memberikan kemudahan, kenyamanan, kecepatan dan keamanan bagi nasabah dalam melakukan transaksi perbankan baik bagi nasabah yang telah memiliki nomor rekening maupun yang belum memiliki nomor rekening.

e. Memperluas jaringan mikro dan menambah jumlah nasabah (customer based).Sesuai dengan temuan dilapangan bahwa bahwa gambaran keberlangsungan layanan BRILink pada PT. BRI (Persero), Tbk. Kantor Cabang Madiun cukup baik ,hal ini dibuktikan dengan

1) Semakin bertambahnya jumlah agen yang menggunakan BRIlink dengan mesin EDC ,kemudahan transaksi dalam penggunaan nya mampu meningkatkan kenyamanan, kecepatan dan keamanan bagi nasabah dalam melakukan transaksi perbankan baik bagi nasabah yang telah memiliki nomor rekening maupun yang belum memiliki nomor rekening,

2) Cepat dan hemat waktu. Banyak nasabah bank, khususnya nasabah bank BRI yang mengeluh karena harus mengantri berjam-jam ketika akan melakukan transaksi. Transaksi di agen BRILink bisa dilakukan dengan cepat dan mudah karena nasabah Agen BRILink tidak terlalu banyak jadi tidak perlu mengantri. Karena itu bisa menghemat waktu nasabah. Pelayanannya juga pasti lebih cepat. Apalagi jika transaksi dilayani langsung oleh Agen (bukan pegawai).

3) Bisa melakukan transaksi kapan saja tidak terikat 
jam kantor. Pada dasarnya, jam kerja agen BRILink ditentukan oleh agen itu sendiri.

4) Bisa Tarik uang, bukan Cuma setor/transfer, tarik uang pun bisa, dengan menggunakan ATM, baik itu ATM BRI ataupun ATM bank lain yang berlogo Link, Prima dan ATM Bersama

5) Bukan hanya transfer, nabung, tarik tunai, dan cek saldo, tapi juga bisa melakukan transaksi lain seperti isi ulang pulsa, bayar listrik, beli token listril, cicilan bank, kartu kredit, dll.

\section{Hambatan-hambatan yang ada} pada penerapan BRILinkPT. BRI (Persero), Tbk. Kantor Cabang Madiun di wilayah Madiun dan sekitarnya Penerapan BRILinkPT. BRI (Persero), Tbk. Kantor Cabang Madiun di wilayah Madiun dan sekitarnya banyak mengalami hambatan dalam penerapanya hal ini dibuktikan dengan :

1) Karena lokasi Agen BRILink jauh dari kota,daerah yang sulit dijangkau dimana mesin ATM tidak ada,sangat menyulitkan Pegawai Bank BRI untuk Maitanance alat dan pemantauan layanan serta memfollowup layanan

2) Banyak terjadi kesalahan dalam input data dikarenakan pemilik toko belum mempunyai pengetahuan tentang alat EDCdan tidak paham tekhnologi

3) masih rendahnya kesadaran masyaraat tentang layanan perbankan atau yang dikenal dengan literasi keuangan

4) Tidak mudah menyakinkan pedagang dan pelanggan lainnya,karena nasabah tidak mendapatkan buku tabungan

5) Resiko terhadap rawan kejahatan karena si agen akan banyak menerima uang dari banyak transaksiDari 
INVENTORY

Jurnal Akuntansi, Prodi. Akuntansi - FEB, UNIPMA, Vol. 1, No.2, April 2018

banyaknya hambatan dalam

penerapan BRILinkPT. BRI

(Persero), Tbk. Kantor

Cabang Madiun di wilayah

Madiun dan sekitarnya maka

PT. BRI (Persero), Tbk.

Kantor Cabang Madiun di

wilayah Madiun harus selalu

memaintance agen serta

sering mengadakan pelatihan

khususnya pelatihan mesin

EDC yang banyak mengalami

keluhan penggunaanya

karena banyak yang belum

\section{DAFTAR PUSTAKA}

Battisti, Michele, Fillipo Belloc, and Massimo Del Gatto. 2012. Unbundling technology adoption and tfp at the firm level. Does it matter?

Bank Indonesia tahun, http://www.bi.go.id/id/perba nkan/keuanganinklusif/Indo nesia/Contents/Default.aspx

Chao, Chih Weih, and Mike Reid.

Consumer Innovativeness and Chines's really new product adoption behavior. Working Paper. 2007

Everdingen, Yvone.M and Eric Waarts. . A multi country study of the aoption of ERP systems: the effect of national culture. ERIM
Report Series of Reserach Management, publish on March

Hedge, Sowmya dan Kotian, Veena D. (2016). Branchless Banking for The Poor as A Part of Financial Inclusion.

Islam, Md. Aminul, T. Ramayah, and Muhammad Muazzem Hossain. 2011. The Adoption of Mobile Commerce Service among Employed Mobile Phone Users in Bangladesh: Self Efficacy as a Moderator. International Business Research.

Moreno, Rosina and Jordi Surinach. 2014. Innovation adoption and Productivity Growth: Evidence for Europe. Regional Quantitative Reserach Group, August 2014.

Nagendra S. dan Shenoy, Narasihma (2011). Financial Inclusion Via Branchless Banking To Extend The Outreach-Case Study ff Corporation Bank.

Nengsih, Novia. (2015). Peran Perbankan Syariah dalam Mengimple-mentasikan

Keuangan Inklusif di Indonesia

Plsek Paul.E. and associates. . Compexity and the adoption of innovation in helath care. Convened by National Institute for Helath Care Management Foundation 
Purwati, Yenny; Franksiska, Rosaly; dan Nugroho, Paskah Ika. (2014). Strategi Peningkatan Kemampuan Adopsi Teknologi Branchless Banking untuk Memperluas Inklusi Keuangan di Masyarakat Pedesaan.

Purwati, Nuraini Retno. (2016). Analisis Penerapan BRILink di Bank BRI Martadinata Kota Malang sebagai Upaya Mendorong Financial Inclusion

Rogers, Everet.M. 1976. New Product Adoption and Diffusion. Journal of Consumer Research Vol.2 March 1976 Rogers, Everet.M. 2003. Diffusion of Innovations: Fifth Edition. New York: The Free Press

Talukder, Majharul, Howard Harris, Gido Mapunda. 2008. Adoption of Innovations by Individuals within Organizations: An Australian Study. Asia Pacific Management Review, accepted on 17 March 2008

Sarma ,2012, Index of Financial Inclusion - A measure of financial sector inclusiveness

Setiowati. (2014). Baitul Mal Wat Tamwil Sebagai Aplikasi Program Financial Inclusion dalam
Peningkatan Akses Bagi

Kesejahteraan Masyarakat Kecil dan Menengah.

Survei Nasional Literasi dan Inklusi Keuangan (SNLIK) ,2016 Otoritas Jasa Keuangan (OJK)

https://mediaasuransinews.c o.id/2017/02/02/hasilsurvei-ojk-2016-indeksliterasi-dan-inklusikeuangan meningkat/https://afidburha nuddin.wordpress.com/2013 /05/21/pengumpulan-datadan-instrumen-pe nelitian/

Tama ,2015 Studi Financial Inclusion dan Financial Deepening di Indonesia,Universitas Jember

Wejnert, Barbara. 2002. Integrating Models of Diffusion of Innovations: A Conceptual Framework. Annual Review Sociology Lainnya: tabloid kontan 6-12 april 2015 